УДК 904.7.031.1(1-924,57)

DOI: $10.18384 / 2310-676 \mathrm{X}-2020-5-56-63$

\title{
COPPER AGE-BRONZE AGE TRANSFORMATION AND EVOLUTION OF THE EARLY BRONZE COMMUNITIES (IV-III MILLENNIUM CAL. BCE)
}

\section{Nikolova}

\author{
Karlovo Academy, 3 Pazarna St., Karlovo 4300, Bulgaria \\ \& Open Global Research Academy, Salt Lake City, Utah, USA
}

\begin{abstract}
Aim. To elaborate on the existing theoretical models describing cultural processes in the Balkans during the $4^{\text {th }}$ and $3^{\text {rd }}$ millennia cal. BCE from the perspective of the archaeology of pre-historic societies. Methodology. The research was conducted using the methods of synthesis and comparative analysis, as well as interpretation of well-known and novel archaeological records.

Results. An evolutionary model was developed to describe two types of communities in the Balkans, including traditional and interactive communities.

Research implications. The research results contribute to the theory of evolution of culture in Prehistory, thereby elucidating our understanding of cultural processes in the Balkans during the $4^{\text {th }}$ and $3^{\text {rd }}$ millennia cal. BCE.
\end{abstract}

Keywords: Balkans, Copper Age, Early Bronze age, archaeology of pre-historic societies, traditional communities, interactive communities

\section{ТРАНСФОРМАЦИЯ И ЭВОЛЮЦИЯ СОООБЩЕСТВ РАННЕБРОНЗОВОГО ВЕКА ОТ ЭНЕОЛИТА К БРОНЗОВОМУ ВЕКУ (IV-III ТЫСЯЧЕЛЕТИЯ ДО НАШЕЙ ЭРЫ)}

\section{Николова Л.}

Академия в Карлово, 4300, Карлово, ул. Пазарна, д. 3, Болгария

Открытая глобальная исследовательская Академия, Солт Лейк Сити, Юта, США

\section{Аннотация}

Цель. Расширить теоретические модели культурных процессов на Балканах в IV и III тысячелетиях до н.э. с точки зрения археологии древних обществ.

Процедура и методы. В исследования использованы синтез, сравнительный анализ и интерпретация традиционных и новых археологических данных.

Результаты. Разработана эволюционная модель, основанная на двух типах обществ на Балканах: традиционного и интерактивного.

Теоретическая и/или практическая значимость. Результаты исследования способствуют дальнейшему развитию теории эволюции культуры первобытных обществ и обеспечивают более глубокое понимание культурных процессов на Балканах в период IV и III тысячелетий до н.э.

Ключевые слова: Балканы, медный век, ранний бронзовый век, археология древних обществ, традиционные общества, интерактивные общества

\section{Introduction}

Materiality of Prehistory is the primary and most important source for understanding the longest period of human history. It has different dimensions, including material cul-

(с) СС ВҮ Николова Л., 2020. 
tureproduced by people as well as biological culture (plant, animal, and human remains) supplemented by the prehistoric geographical culture. Beyond the prehistoric material database, other sourcesexist for which genealogical roots go deep into prehistory--most importantly, historical linguistics.

\section{Setting}

The biggest problem related to prehistoric materiality is that evolution is under the pressure of time, and we need a considerable cultural material change to be able to recognize its historical dimension. This specific example of the historical record very easily opens the door to different migration theories. In particular, it prompts consideration of the theories of the Indo-European population's migration from east to west (the Aryan theory), from west to east (the Steppe theory), and from southeast to northwest (the Neolithic theory). None of them is without considerable gaps, however, and all of them are based on selective records and limited methodology[2].

From the perspectives of the Balkans, it appears thatthe problem of Copper AgeBronze Age transformation in earlier $4^{\text {th }}$ millennium cal. BCE in this region is a subject of debate in both past and modern historiography. However, in most of the cases, the debate was/is not about the records and their interpretation, but about how bigger theories have been applied to this chronological span and the documented cultures. Deductive reasoning dominates, including the most recent genetic replication of some of the archaeological models, in particular that of $\mathrm{M}$. Gimbutas, although the latter was buried by the archaeological critical theoryof the $20^{\text {th }}$ century. The main gap in all migration models that propose invasions from the presumably proto-Indo-European region to the north of the Black Sea in westerly and southwesterly directions is the inability to incorporate the diversity of the records into a complex model replaced by the flattened population change model, which is easy to build but difficult to defend.
My task in this work is difficult: following the main directions of my research over the last several decades, I will model a Copper Age-Bronze Agechangeas a transformation from one type of community into another type of community. The meaning of this transformation comes from communities with a traditional pattern of reproduction changing into interactive communities in which the tradition functioned as an interactive mechanism of development showing cohesion between closer and more distant neighbors. That meansthe interaction itself becomes a pattern of tradition.

The earlier $21^{\text {st }}$ century is more beneficial when researchinglater prehistoric material evidence from Eastern and Southeastern Europe. Embracing the democracy ushered in after 1989, the devastating practice of excavation over large areas with rough methodology has been gradually abandoned, and the main new data come from rescue excavations undertaken at different scales. Despite some exceptions, Prehistory is no longer a subject of political interest or a career path for people with specific political affiliations, and this creates a more academic environment for research and interpretation of the data. Beyond local archaeologists, international teams have been working to improve the quality of the research and to make Balkan prehistoric records a reliable source for interpretation based on the grounded theory. Different collections of research results also attempt to develop the understanding of the cultural processes using diverse methodologies (e.g. [27;11;22;3]). The genetic data were also included in the research, with still very problematic conclusions (see [15] and ref. cited there).

The goal of this work is to develop an argument about the genesis and evolution of the interactive communities in the Balkans during the Bronze Age (abt.mid $4^{\text {th }}-3^{\text {rd }}$ millennium cal BCE). The general chronological frames follow Nikolova 1999, including the following stages:

Stage 1. Early Bronze I: abt. ?3600/3500abt.3000 BCE 
Stage 2. Early Bronze II: abt. 3000-abt. 2500/2400 cal BCE

Stage 3. Early Bronze III: abt. 2500/2400abt. 2000 cal BCE

\section{Genesis and evolution of the Early Bronze communities in the Balkans}

\section{Early Bronze I}

One of the most important directions of development of the hypothesis of interactive communities is the interpretation of the archaeological evidence from the Balkans and Anatolia [13]. Specific pottery shapes even connect the Balkans with Kurusay. That, along with later $20^{\text {th }}$-century outlines [12] and some results fromnewer excavations, shows the genesis of the Early Bronze Age in the Balkans was a result of cultural interactions of communities, the origin of which was in different homelands - the Balkans, Anatolia / North Aegean, Central Europe and Northwest / North Black Sea.

The first component of Early Bronze communities included descendants of the Final Copper communities of Cernavoda I, Sălcuța IV-Telish IV, Yagodina, and similar communities of this period. For possible climatic and economic reasons, the population during the Final Copper Age in the Balkans gradually decreased. The general transformation from an agricultural toward a stockbreeding-based economy transformed the reproduction pattern into smaller families with demographic consequences. Among the recent findings is the site of Bezhanovo in Central Bulgaria from earlier $4^{\text {th }}$ millennium cal. BCE[28]. The pottery of this site clearly shows the graduate devolution of the Krivodol-Sălcuța-Bubanj ceramic style and elements of Sălcuța IV without Scheibenhenkel components.

At the beginning of the Early Bronze Age, the second very important tendency was the population's interaction with Anatolia, along withthe possible small-scale migrations from Anatolia to the Balkans. The biggest argument for such a hypothesis is Yunatsitetell,where urn baby burials were very popular-in the earlier Bronze Age levels, in particular. Although Ezero is close to Anatolia, such burials are not specific to the tell. Since the material culture of Sitagroi IV has an analogy in Yunatsite I culture from the Western Upper Thrace (Dubene-Sarovka IIA), we believe part of the population in Thrace came from the North Aegean, possibly rooted in northwest Anatolia. Very important new discoveries from Katarraktes cave [23] add new characteristics to the Early Bronze in the Southern Balkans - the life in the caves of the stockbreeders which was typical of the Final Bronze Age in the Balkans, continued to characterize the style of life of Balkan population marking the continuity between the Final Copper and Early Bronze. The archaic features of the pottery of phase $B$ include distant analogies even in Cernavoda I [23] andprovide excellent evidence of the role of the interactions for the formations of the Early Bronze Age communities.

The very strong integration of the Lower Danube-Middle Danube communities has an expression in the Cernavoda III-Boleraz horizon. These interactions, evidenced most strongly in the similarity of pottery, can be explained by economic exchange and the free movement of people. This includes intermarriages and inner migrations of households mainly in the direction from west to east, since the Lower Danube was obviously considerably depopulated during the Final Copper Age. The hallmark of the Cernavoda III-Boleraz ceramic style - the elder ornament - originated in the Middle Danube, and it did not penetrate Thrace. This allows us to think about some ethnographic functions of the motif and the purposeful differentiation of the Thracian communities.

Last but not least, the penetration of the Pit Grave Culture from the northwest Black Sea toward the Lower Danube basin took place during the later Early Bronze I, with some traces also in northern Eastern Thrace. The material culture, and especially the gradualincrease of the EBA I settlements in the Balkans (with the exception of Dobrudzha), clearly show PGC was a small population 
component of the Balkan interactive communities during EBA I. Obviously, they occupied the steppe region of the eastern Lower Danube and easily became part of the Balkan multicultural interactive population. At the same time, new data and the use of the traditional typological contemporary approach (see e.g., [4] and cited lit.) clearly demonstrates that archaeologists are still far away from proposing models based on the grounded theory, and that we need innovations both in the methodology of excavations and in the interpretation of the archaeological evidence to promote more detailed pictures of the cultural processes related to the steppe-origin population presence in the Balkans.

Early Bronze Age I occupation on tells like Ezero (the earliest EB horizons) and Yunatsite (the earliest EB horizons) together with Dubene-Sarovka IIA covers only the later part of the period. The team of Drama believes that the Early Bronze I site resembles Cernavoda III culture. None of them can be dated to the very beginning of Early Bronze in Thrace. Accordingly, despite of the visible progress of filling with archaeological evidence the $4^{\text {th }}$ millennium cal BCE, there are many chronological gaps at micro- and mezoregional levels.

Also, it is difficult to distinguish a specific chronological horizon of EB I tumuli and graves of PGC in the Balkans if we follow the grounded theory. For the time being, the problem is more theoretical - whether the migration was a graduate process during EB I and EB II, or the EB II buried population were descendants of EB I immigrants.

The archaeological characteristics of PGC in the Balkans and its chronological and cultural interrelations with the other Balkan cultures do not recognize the barriers of this culture as invaders or "mass migration" (e.g. $[18 ; 17 ; 1 ; 7 ; 21])$. PGC communities were pastoral immigrants who either were able to develop social systems of interacted households, or integrated with the local sedentary and semi-sedentary communities.

\section{Early Bronze II}

This was the period when the Balkan Early Bronze Age cultures flourished. The economic infrastructure was based on agriculture, stockbreeding, bronze metallurgy, and internal and external trade. It is very interesting to hypothesize how the interactive communities understood trade and how it functioned during the Early Bronze II, since trade was the main contributor to the prosperity of the communities.

One of the components of the hypothesis is the fact that different communities kept pottery as an ethnographic indicator of their cultural and possibly ethnical identity. Despite similar techniques of decoration and general similarities in the ceramic styles, the Balkan communities lived in their own ethnographic regions, determined by specific ceramic styles - Ezero and Yunatsite in Upper Thrace, Ezerovo II and Sozopol on the western Black Sea shore, SitagroiVa-Dikili Tash IIIB in the Northern Aegean, Pernik in Southwest Bulgaria, Coțofeni II-III in the western Lower Danube basin, Kostolac in the western Lower Danube, Vičedol in the southern Lower Danube, etc. Pit Grave Culture continued to occupy Dobrudzha and northern Central Bulgaria (Goran-Slatina), but the data do not show that Early Bronze II was a period of massive invasion. In contrast, it is very likely that the households of Pit Grave Culture in the eastern Lower Danube followed the social structure of the other Balkan ethnographic regions, and the absence of opportunities for free movement made them resistant to accepting big new groups of Pit Grave Culture from the Northwest Black Sea. Respectively, many PGC graves and tumuli in Coțofeni culture from the Early Bronze II could be a result of inner movements in the Balkans, including intermarriages. This is also the period of vast expansion of Coțofeni ceramic style in Eastern Serbia [24; 8].

Regional sustainability and prosperity resulted in the increase in both the population and the individual wealth of the households. Gold earrings and hair ornaments had be- 
come standard expressions of prosperity, not a reflection of a specific high social status [5]. They show the role ofgathering of placer gold, although the main exchange was of bronze implements and weapons. During the earlier $3^{\text {rd }}$ millennium, the Balkans developed as a region and became an integral part of the Anatolian-Aegean-Balkan cultural system, as seen in the evidence of the trade of bronze implements/weapons. Meanwhile, the society evolved into a system of interactive chiefdoms, the sustainability of which was due to the general prosperity of the communities.

Among the most important bronze finds during Early Bronze II, which continued to be produced in Early Bronze III, as well, were the flange axes. They were distributed on both sides - to the north of the Danube basin[20] and to the south of the Danube [12]. Of special interest is the flange axe from Dubene-Sarovka, which was made of lead bronze and shows interactions of technology between two sizable regions: while lead bronze was characteristic of the Aegean, the shape was typical of Central Europe. Also, the encrusted pottery with typical zigzag ornament was very popular at DubeneSarovka IIB, connects Western Thrace with SitagroiVa and even with Thasos. The technics and ornamentation on the bowl from Limenaria ([9]: Fig. 25) is identical with the ceramic style of Dubene-Sarovka IIB.

In the context of the general picture of the Early Bronze II, the discovered gold jewelry from Dubene-BalinovGorun [16] was not an exception for the Balkans, but a sign of the equally developed processes of accumulation of wealth in Anatolia, the Aegean, and the Balkans. Another such sign is the Rupite cemetery in Southwest Bulgaria [10].

This is the general difference between the traditional societies of theLate Copper Age and the interactive societies of the Early Bronze II - the most representative wealth was reserved during the Later Copper Age for single leaders as an expression of high socialreligious status (Varna gold cemetery). During Early Bronze II,representative wealth was a marker of the prosperity of the interactive communities, without being dependent on the political-religious hierarchical structure.

\section{Early Bronze Age III}

It seems that, during Early Bronze III, the economic center of the Balkans moved into the Carpathians. Guluvovo shows that Upper Thrace continued contacts with Anatolia, but gradually, the lifestyle was transformed into one in which stockbreeding societies dominated, with possible central places.

A prototype of such a structure may be Dubene-Sarovka. Although without visible hiatus on the site, the thickness of the cultural layer is inconsiderable in comparison to the Yunatsite tell. This could be a result of the lower intensity of life and of the fact that that part of the community was made up of stockbreeders who lived in the Stara Planina Mountains most of the time. Since there was production of bronze implements and weapons at Dubene-Sarovka, the gold jewelry in the style of Anatolian Troy jewelry could be a result of exchange or of travelingjewelers. Unfortunately, the nature of the Balinov Gorun site has remained unclear despite the lengthy excavations. The opportunity for numerous hypotheses - from the destroyed shallow cemetery to a place where the jewelry was hidden with the hope that it would be found after seasonal stockbreeder migration that never happened, makes it impossible to build reasonable, solid, historical hypotheses. No analysis of the gold is provided that would show whether the gold was of local origin. For the time being, it is just a sign of prosperity of the Yunatsite culture community during Early Bronze II-III, and it remains the largest Early Bronze gold jewelry finding in the Balkans.

Some signs of tensions between Thracian communities are well documented through pottery. In the Yunatsite culture during Early Bronze III, pointed-bottom cups were very popular. They were found only as an exception in the Ezero culture. Obviously, the communities of the Ezero culture did not accept the fashion of drinking alcohol that was common among Yunatsite males, despitethe genuine attractiveness of the cups and the 
existing strong interactions documented in numerous other similarities in the pottery and in the metal and stone industries. At the same time, the Thracian communities did not accept the drinking habits of the Aegean and Anatolian communities. It seems there was a regional dignity in the communities a strong expression of the oppositional wethey, but only at the ethnographic level of feasts, songs, and folk rituals. Gradually, and for a complexity of reasons, the economic strategies of the mobile and semi-mobile stockbreeding styles of life won out in Thrace, much like in the Final Copper Age.

The life to the north of the Danube in the Balkans continued with strong integrations with the Middle Danube basin (to the west), and with the northwest Black Sea (to the east). The Carpathian communities interacted with the North, as well.

\section{Considerations and conclusion}

No records exist that can replace the material culture as the base of understanding the later prehistory of the Balkans. The Early Bronze Age Balkan material culture shows interactive communities with specific ethnographic characteristics. The formation of the sustainable Early Bronze economic and cultural system in the Balkans was built first by a multicultural society during Early Bronze I. This was a period of integration of communities, the origin of which was in the Balkan Final Copper Age, but also in Anatolia, the Middle Danube, and the Northwest Black Sea. The material culture during Early Bronze I-II is the strongest voice against any one-directional invasion hypothesis and any attempt to use archaeological data to explain the Indo-
European language distribution. Most likely, the interactive theory is the most reasonable model for resolving this linguistic problem, since the early I.-E. languages had similar structures, but also considerable differences. That means that, over vast territories, the Early Bronze Age was a period of unification of the cultural systems to serve more effective interactions that assisted the strategies of sustainable and secured communities. Development of an interactive language was a sort of law embraced by the elites, for whom close and distant trade and social-political communication were the bases of prosperity.

The later $20^{\text {th- }}$ and early $21^{\text {st }}$-century discoveries including the Sarovka and BalinovGorun sites at Dubene in western Upper Thrace show that, during the Early Bronze Age in the Balkans,prosperous communitieslived and had the opportunity to accumulate and express their wealth. Wealth became a standard of sustainable interactive communities, for whom trade, especially with metal, was extremely important. The metal industry developed on numerous sites, and the mining of copper was one of the integrative factors, along with placer gold. It is still unclear how important Ada gold mining was for Prehistory. It seems, however, that the Carpathians gradually developed as the leading mining copper source, and the later Early Bronze societies continued to flourish in this region. Meanwhile, south of the Balkans, the presumed process is a community transformation toward stockbreeding as characterizedin the later Bronze Age in $2^{\text {nd }}$ millennium cal BCE.

Статья поступила в редакиию 03.06.2020

\section{REFERENCES}

1. Comșa A., Bonsall C., Nikolova L. (eds.). Facets of the Past. The Challenge of the Balkan Neo-Eneolithic. Proceedings of the International Symposium Celebrating the $85^{\text {th }}$ Birth Anniversary of Eugen Comşa. 6- 12 October 2008. Bucharest, Romania. Bucharest, Romanian Academy Publ., 2013, 768 p.

2. Demoule J.-P., Laks B., Cleuziou S., Encrevé P. Origins and Evolution of Languages: Retrospectives and Perspectives. Laks B. (ed.). Origin and Evolution of Languages: Approaches, Models, Paradigms. London, Equinox Publishing Ltd., 2008. pp. 1-28.

3. Flaux C., Rouchet P., Popova Tz., et al. An Early Bronze Age pile-dwelling settlement of discovered in Alepu lagoon (municipality of Sozopol, department of Burgas), Bulgaria. In: Méditerranée, 2016, vol. 126, pp. 57-70. 
4. Frînculeasa A., Mirea P., Trohani G. Local cultural settings and transregional phenomena: on the impact of a funerary ritual in the Lower Danube in the 4th millennium BC. In: Buletinul Muzeului Județean Teleorman, Seria Arheologie, 2017, vol. 9, pp. 75-116.

5. Frînculeasa A., Garvăn D., Mărgărit M., et al. Between worlds and elites at the beginning of the Early Bronze Age in the Lower Danube Basin: A pluridisciplinary approach to personal ornaments. In: Archaeological and Anthropological Sciences, 2020, vol. 12. Available at: https://doi.org/10.1007/s12520020-01177-0

6. Ganetsovski G. The prehistoric settlement in the Ezeroto locality near the village of Borovan, Northwestern Bulgaria.TsirtsoniZ. (ed.). The Human Face of Radiocarbon. Reassessing chronology in prehistoric Greece and Bulgaria, 5000-3000 cal BC (TMO 69). Lyon, Maison de l'Orient et de la Méditerranée Publ., 2016, pp. 115-123.

7. Horváth T. The Boleráz, Baden and Kostolac Cultures in the Late Copper Age and Early Bronze Age: Their Chronological and Spatial Distribution, and Intercultural Connections. Specimina Electronica Antiquitatis. 2011. vol. 12. pp. 51-112.

8. Kapuran A., Bulatović A. Culture on the Territory of North-Eastern Serbia. Starinar Publ., 2012. vol. 62 , pp. $1-30$.

9. Koukouli-Chrysanthaki C., Papadopoulos S. The island of Thasos from the Neolithic to the Early Bronze Age. Excavation data and absolute dates. Tsirtsoni Z. (ed.). The Human Face of Radiocarbon. Reassessing chronology in prehistoric Greece and Bulgaria, 5000 -3000 cal BC (TMO 69). Lyon, Maison de l'Orient et de la Méditerranée Publ., 2016. pp. 339 - 358.

10. Leshtakov K. Bronze Age Mortuary Practices in Thrace: A Prelude to Studying a Long-term Tradition. Borgna E., Celka S.M. (eds.). Ancestral Landscape. Burial Mounds in the Copper and Bronze Ages. Proceedings of the International Conference held in Udine, May $15^{\text {th }}-18^{\text {th }} 2008$. Lyon, Maison de l'Orient et de la Méditerranée Jean Pouilloux Publ., 2012, pp. 567-577.

11. Nikolov V., Sheer W. (eds.). Der Schwarzmeerraum von Neolithikum bis in die Früheisenzeit (6000600. v. Chr.). KulturelleInterferenzen in der Zirkumpontischen Zone und KontaktemitihrenNachbargebieten. Leidorf, Rahden/Westf. 2016. 536 p.

12. Nikolova L. The Balkans in Later Prehistory. Oxford, BAR International Series. 1999. 442 p.

13. Nikolova L. Balkan-Anatolian Cultural Horizons from the Fourth Millennium BC and Their Relations to the Baden Cultural Complex. Furholt M., Szmyt M., Zastawny A. (eds.). The Baden Complex and the Outside World. Bonn, Dr. Rudolf Habelt GmbH Publ., 2008. pp. 157-166.

14. Nikolova L., Merlini M., Comşa A. (eds.). Western-Pontic Culture Ambience and Pattern. In memory of Eugen Comşa. De Guyter Open. 2017. 356 p.

15. Nikolova L. Cultural Genomics and the Changing Dynamics of Cultural Identity. New York, Nova Science Publ., 2018. 262 p.

16. Nikolova L. Dubene and Troy: Gold and Prosperity in the Third Millennium Cal. BCE in Eurasia. In: Stratum Plus, 2018, no. 2, pp. 61-68.

17. Nikolova L. Pit Grave Culture in the Danube Basin: Immigrants or Invaders? (Cultural Evolution and Language Diversity). In: Comas A., Hortopan D. (eds.). Digging in the Past of Old Europe. Studies in Honor of Cristian Schuster at His 60th Anniversary. Brăila, EdituraIstros a Muzeului Brăilei Carol Publ., 2019. pp. 277-282.

18. Nikolova L. 2000. The Pit Grave Culture in the Balkans (Dynamics of the Structure of the Burial Rites and its Relation to other Early Bronze Age Cultures). In: Stratum Plus, 2000, no 2, pp. 423-458.

19. Oy H. West Anatolian mining in Early Bronze Age (3000-2000). In: Journal of Ancient History and Archaeology, 2017, vol. 4, no 1, pp. 12-24.

20. Preda-Bălănică B., Frînculeasa A., Garvăn D., Constantinescu B., Stan D. Unfortuitous accidents Prehistoric metal artefacts recently detected in northern Muntenia (Prahova County, Romania). Sîrbu, V.Comşa A., Hortopan D. (eds.). Digging in the Past of Old Europe. Studies in Honor of Cristian Schusterat his 60th Anniversary. Târgu Jiu - Brăila: Istros a MuzeuluiBrăilei „Carol I” Publ., 2019. pp. 321-339.

21. Preda-Bălănică B., Frînculeasa A., Heyd V. The Yamnaya Impact North of the Lower Danube. A Tale of Newcomers and Locals. In: Bulletin de la Société préhistoriquefrançaise, 2020, vol. 117, no. 1, pp. 85-101.

22. Popa C. I. (ed.). The Carpathian Basin and the Northern Balkans between 3500 and 2500 BC: Common Aspects and Regional Differences. Cluj-Napoca, Mega Publ., 2016. 262 p. 
23. Siros A., Miteletsis M. The "Katarraktes" Cave at Sidirokastro, Serres District. In Tsirtsoni Z. (ed.). The Human Face of Radiocarbon. Reassessing chronology in prehistoric Greece and Bulgaria, 5000-3000 cal BC (TMO 69). Lyon, Maison de l'Orient et de la Méditerranée Publ., 2016. pp. 317-337.

24. Spasić M. Coțofeni Communities at Their Southwestern Frontier and Their Relationship with Kostolac Population in Serbia. In: Dacia, 2010, vol. 54, pp. 157-175.

25. Todorova N. The Final Chalcolithic site in the "Gradishteto" locality near the village of DolnoDryanovo, Southwest Bulgaria. Tsirtsoni Z. (ed.). The Human Face of Radiocarbon. Reassessing chronology in prehistoric Greece and Bulgaria, 5000-3000 cal BC (TMO 69). Lyon, Maison de l'Orient et de la Méditerranée Publ., 2016. pp. 169-186.

26. Todorova N., Avramova M. The Yagodina Cave and the final stages of the Chalcolithic in the Western Rhodope Mountains. Tsirtsoni, Z. (ed.), The Human Face of Radiocarbon. Reassessing chronology in prehistoric Greece and Bulgaria, 5000-3000 cal BC (TMO 69). Lyon, Maison de l'Orient et de la Méditerranée Publ., 2016. pp. 249-268.

27. Tsirtsoni Z. (ed.). The Human Face of Radiocarbon. Reassessing chronology in prehistoric Greece and Bulgaria, 5000-3000 cal BC (TMO 69). Lyon, Maison de l'Orient et de la Méditerranée Publ., 2016. 516 p.

28. Valentinova M. An Early Fourth Millennium Settlement Near the Village of Bezhanovo, Lovech Region. Tsirtsoni Z. (ed.). The Human Face of Radiocarbon. Reassessing chronology in prehistoric Greece and Bulgaria, 5000-3000 cal BC (TMO 69). Lyon, Maison de l'Orient et de la Méditerranée Publ., 2016. pp. 99-114.

\section{INFORMATION ABOUT THE AUTHOR}

Nikolova L. - PhD (Philosophy), professor at Karlovo Academy, Karlovo, Bulgaria \& Open Global Research Academy, Salt Lake City, Utah, USA;

e-mail: lnikol59@abv.bg

\section{ИНФОРМАЦИЯ ОБ АВТОРЕ}

Л. Николова - доктор философии, профессор Академии в Карлово, Болгария, и Открытой Глобальной исследовательской академии, Солт Лейк Сити, Юта, США;

e-mail: lnikol59@abv.bg

\section{ПРАВИЛЬНАЯ ССЫЛКА НА СТАТЬЮ}

Николова Л. Трансформация и эволюция соообществ раннебронзового века от энеолита к бронзовому веку (IV-III тысячелетия до нашей эры) // Вестник Московского государственного областного университета. Серия: История и политические науки. 2020. № 5. Циркумпонтика. Вып. II. C. 56-63.

DOI: $10.18384 / 2310-676 \mathrm{X}-2020-5-56-63$

\section{FOR CITATION}

Nikolova L. Copper Age-Bronze Age transformation and evolution of the Early Bronze communities (IV-III millennium cal. BCE). In: Bulletin of the Moscow Regional State University. Series: History and Political Sciences, 2020, no. 5, Circumpontica, iss. II, pp. 56-63.

DOI: $10.18384 / 2310-676 \mathrm{X}-2020-5-56-63$ 